\title{
Forest Encroachment: Alternative Regulation
}

\author{
Mhd. Fahmi Siregar ${ }^{1}$, Arief Wahyudi², Reh Bungana Beru Perangin-angin ${ }^{3}$, Yusna Melianti ${ }^{4}$, \\ Fazli Rachman ${ }^{5}$, Abdinur Batubara ${ }^{6}$ \\ \{fahmisrg71@gmail.com¹․rf.wahyudi@gmail.com² ${ }^{2}$,rehbungana@unimed.ac.id ${ }^{3}$, \\ yusmelianti@gmail.com ${ }^{4}$, fazli.rachman@unimed.ac.id ${ }^{5}$, abdinurbb04@gmail.com 6 \} \\ Universitas Negeri Medan, Jalan Willem Iskandar, Pasar V, Medan Estate, Medan, Indonesia ${ }^{1,2,3,4,5,6}$
}

\begin{abstract}
Since the eruption of Mount Sinabung, the government has sought to relocate victims. Encroachment of great forest park (Tahura) occurred because of the lack of relocation area. This evaluative paper is intended to select, determine, and what legal remedies are effective based on normative-empirical legal research. This, a better regulation can be found based on data obtained from an analysis of government efforts to tackle. Thus, a better regulation can be found based on data collected from an analysis of government efforts to tackle illegal logging in the Tahura. The North Sumatra Provincial Regulation is expected to focus on the role of the UPT and its apparatuses in protecting and managing the Tahura to maintain its function as a protected forest.
\end{abstract}

Keywords: forest, great forest park, forest encroachment

\section{Introduction}

In 2010 Mount Sinabung began its first eruption after 400 years of inactivity. The eruption had a very broad impact on the communities around Sinabung, especially Karo District. The National Disaster Management Agency (BNPB) noted that thousands of residents experienced the direct impact of the Mount Sinabung volcanic ash [1]-[3].

The continuing eruption caused people to evacuate and lose their homes and agricultural land. Meanwhile, Victims who have not lost their homes and agricultural land, cannot farm and failed to harvest are caused by the volcanic ash of Mount Sinabung. The government responded by planning to relocate the communities around Sinabung in 3 (three) stages. Through the Ministry of Environment and Forestry, the government gave 6,300 hectares of land which were sufficient for residential and agricultural. However, all these lands have been controlled by other parties. While waiting for the relocation process, the community is placed in a temporary shelter [1], [4], [5].

Efforts to relocate Mount Sinabung eruption victims have not been completed due to lack of relocation land. Victims of eruption assume the government does not provide the right solution to their problems [6][7]. This situation causes the victims of the eruption of Mount Sinabung are continuing their activities in a dangerous zone of eruption [8][9] and some others are cutting down forests in the Greater Forest Park (Tahura) area for agricultural and residential land.

Forests are an inseparable part of the environmental ecosystem. Undisturbed forests provide plenty of space and opportunities to balance environmental ecosystems [10]. Forests have several functions that are important for human welfare [11]. Forests provide a variety of valuable products [12]. Forests provide a number of important ecological benefits [13]. Forests are the 
most significant reservoir of terrestrial carbon, which can maintain global climate balance, protect soils from degradation, and prevent desertification [14]. The international community is increasingly focusing on carbon sequestration through better forest management as the most effective tool in combating climate change [15].

Community action on Tahura will disturb the balance of the ecosystem. It is important to see the government's efforts to solve the problem of cultivating Tahura illegally as well as how alternative policies are right to resolve the issue. Because forests that are managed sustainably have tangible environmental, social, and economic benefits [16]. However, preliminary studies show that refugees who were victims of Mount Sinabung have been looting forests in Tahura Karo District. According to the data, the amount of forest that was tilled was almost 800 hectares in 2017 in the Bukit Barisan Tahura area and Mount Leuser National Park (TNGL) in Karo and Langkat Districts.

\section{Research Method}

The data in this paper were obtained from evaluative empirical normative law research. This research method ends to look at and determine better laws for resolving illegal forest cultivation. Normative legal research is conducted to identify the principles and values that form the basis of a legislative formulation. Analyzing the mutual relationship between legal facts and social facts [17]. Empirical legal research is used to produce theories about the existence and function of law in society, along with the changes that occur in the process of social change. [18]. The study was conducted in Karo Regency, North Sumatra Province. Primary and secondary data were analyzed using qualitative data analysis, which was juridical in nature [19]. Conclusions are drawn using deductive and inductive methods.

\section{Result and Discussion}

Research conducted shows that the location of illegal forest encroachment occurred on the left and right along the crossing of Karo District towards Langkat District. The area of forest encroachment along the causeway is around $10 \mathrm{KM}$ around Kuta Rakyat Village, Naman Teran Sub-district, Karo District. Uniquely, forest encroachment occurred in the Karo District, while forests in the Langkat District area were still relatively intact. The expansion of the Great Forest Park (Tahura) area was carried out by Mount Sinabung eruption refugees who were unwilling to be relocated to the village of Siosar, Karo District.

Tahura area covers 4 (four) districts, namely: Karo, Langkat, Deli Serdang, and Simalungun. Then it is important to alternative policies of the government of North Sumatra or the institutions above it to solve these problems. Every policy that will be implemented must be incorporated into regional regulations in the hierarchy of statutory regulations. Thus the efforts made by the government of North Sumatra have validity [20]. Realizing the function of forests for the welfare of the people through development needs alternative policies through the law, then manifested in social reality [20].

The results showed that the government had made preventive, repressive, and recovery efforts. Forest restoration operations carried out are planned in 2017. The recovery operation has been postponed because the relocation has not been completed. So that there needs to be serious and quick handling in dealing with the problem of victims of the Mount Sinabung 
eruption. Moreover, the forest encroachers claimed that the victims of the Mount Sinabung eruption did not have a place to stay and agricultural land.

Tahura encroached, controlled, and occupied to take forest products, establish houses and plantations as business land. The perpetrators take wood, topsoil, and protected animals. Efforts to relocate victims of the Mount Sinabung eruption have been carried out by providing land in the Siosar area. But the victims searched the land for reasons that were not supportive accessibility. Moreover, the victim prefers to be placed on the side of the highway while not all of the relocation sites are located on the side of the highway. Then the government needs to take strict action so that victims can stay and move on the land that has been provided.

Encroachment occurred in conservation forests in the Tahura area. The conservation forest in question is a forest area that should not be disturbed at all because of the main function of preserving plant and animal diversity and its ecosystem [21]. The area of forest that has been added has reached more than $560 \mathrm{Ha}$ from 51,600 Ha wide Tahura [21], [22].

The government must ensure that victims of the Mount Sinabung eruption acquire land and settle into developing agricultural land and settlements in Siosar. Sustainable forest protection is the responsibility and obligation of the government and the community [23]. Capacity building and community empowerment in a participatory, fair, and environmentally friendly manner [21]. It is important to increase community participation in managing and protecting forests as part of the environment [24]-[28]. Efforts to restore the Tahura area must be carried out with the community by ensuring that the economic and justice dimensions of the victims and the community around Mount Sinabung are protected and fulfilled. That way, the government's efforts to improve the function of Tahura for the benefit of the environment can work. The Provincial Government needs to strengthen the role of technical implementation Unit (UPT) Tahura Bukit Barisan to protecting, managing, and maintaining forest functions. Forestry police personnel are not comparable to the area of Tahura that must be monitored. The number of forestry police personnel for the area is only 8 . The lack of supervision of forest encroachers considers as if the forest area has no owner. Because of UPT Tahura Bukit Barisan as a forest management unit as control access in Tahura management [29].

The need for synergy of all parties involved to overcome the problems in Tahura. An ideal, effective communication system, fast feedback, trust, and creativity [30] are needed in forest management. The combination of various organizational resources in this context is the implementation of tasks, authority, and management responsibilities. Therefore urgently needed a government policy that can be the basis of land recovery by the manager of the Bukit Barisan Tahura after the eruption of Mount Sinabung.

\section{Conclusion}

There needs to be serious and quick handling in dealing with the problem of Mount Sinabung eruption victims. Strengthening the role of UPT Tahura Bukit Barisan in protecting, managing, and maintaining forest functions. The need for synergy of all parties involved to overcome the problems in Tahura.

\section{References}

[1] M. Leandha, "Usul BNPB Relokasi Pengungsi Sinabung ke Kawasan Hutan Dikritik,"
Kompas.com,
2017.
[Online].
Available: https://regional.kompas.com/read/2017/02/10/21043641/usul.bnpb.relokasi.pengungsi. 
sinabung.ke.kawasan.hutan.dikritik?page=2. [Accessed: 10-Sep-2017].

[2] S. P. Nugroho, "Sinabung Meletus Dua Kali, 17.094 Mengungsi," www.bnpb.go.id, 2013. [Online]. Available: https://www.bnpb.go.id/sinabung-meletus-dua-kali-17-094mengungsi. [Accessed: 29-Sep-2019].

[3] Tempo.co, "Warga di Sekitar Sinabung Diminta Tak Masuki Zona Merah,” Tempo.co, Jakarta, 03-Aug-2017.

[4] I. Harruma, "Relokasi Pengungsi Sinabung Tahap 2 Ditargetkan Rampung Desember," Republika.co.id, 2016. [Online]. Available: https://nasional.republika.co.id/berita/nasional/daerah/16/05/24/o7olxd284-relokasipengungsi-sinabung-tahap-2-ditargetkan-rampung-desember.

[5] J. Wirawan, "Rawan Bencana, Warga di Sekitar Gunung Sinabung 'Harus Direlokasi ," BBC Indonesia, $2016 . \quad$ [Online]. Available: https://www.bbc.com/indonesia/berita_indonesia/2016/05/160522_indonesia_sinabun g_relokasi. [Accessed: 23-Sep-2019].

[6] O. Oktorie, "Model Kebijakan Responsif Pemulihan Bencana Letusan Gunung Sinabung," J. Kapita Sel. Geogr., vol. 1, no. 1, pp. 39-45, 2018.

[7] S. Hanani and A. A. G. Hassan, "Perlawanan Perempuan di Pengusian: Studi Keberadaan Perempuan di Pengungsian Gunung Sinabung, Kabupaten Karo, Sumatera Utara," J. Ilm. Kaji. Gend., vol. 4, no. 2, pp. 141-156, 2014.

[8] H. Wijoyo, Rahmawaty, and A. Rauf, "Kajian Karakteristik Lahan Kawasan Relokasi Pengungsi Erupsi Gunung Sinabung Kabupaten Karo Sebagai dasar Penggunaan Lahan Berbasis Pengelolaan DAS," J. Pertan. Trop., vol. 2, no. 1, pp. 41-53, 2015.

[9] J. I. Perangin-angin, K. Tarigan, and H. Hasyim, "Dampak Erupsi Gunung Sinabung Terhadap Produktivitas dan Pendapatan Petani (Studi Kasus: Desa Perteguhen, Kec. Simpang Empat, Kabupaten Karo),” J. Soc. Econ. id Agric. Agribus., vol. 4, no. 5, 2015.

[10] L. A. Wayburn, "Conservation Easements as Tools to Achieve Regulatory Environmental Goals," Law Contemp. Probs., vol. 175, pp. 175-197, 2011.

[11] L. C. Irland, "The Big Trees Were Kings: Challenges for Global Response to Climate Change and Tropical Forests Loss," UCLA J. Envtl. L. Pol'y, pp. 387-434, 2010.

[12] K. B. Schuz, "New Governance and Industry Culture," Notre Dame Law Rev., vol. 88, no. 5, pp. 2515-2550, 2013.

[13] A. B. Johnson, "If a Tree Falls in a Forest: The Sound of the Maryland Forest Conservation Act in the State and Two of Its Rapidly Developing Counties, Frederick and Washington," 18 U. Balt. J. Envtl. L. 55 , Univ. Balt. J. Environ. Law, pp. 55-77, 2010.

[14] K. Kunzmann, "The Non-legally Binding Instrument on Sustainable Management of All Types of Forests - Towards a Legal Regime for Sustainable Forest Management?," Ger. Law J., vol. 9, no. 8, pp. 981-1006, 2008.

[15] B. Hudson, "Federal Constitutions, Global Governance, and the Role of Forests in Regulating Climate Change," Indiana Law J., vol. 87, no. 4, pp. 1455-1515, 2012.

[16] R. J. Allen, "Sustainable Forestry in Virginia: Opportunities for Overdue Legislation and Options for Private Landowners.," Appalach. JL, vol. 7, no. 1, 2007.

[17] Z. Barus, P. Labu, and J. Selatan, "Analisis Filosofis Tentang Peta Konseptual Penelitian Hukum Normatif dan Penelitian Hukum Sosiologis,” J. Din. Huk., vol. 13, no. 2, pp. 307-318, 2013.

[18] S. Wignyosoebroto, Hukum: Paradigma, Metode dan Dinamika Masalahnya. Jakarta: Elsam, HuMa, 2002.

[19] M. S. Sumardjono, Argumentasi Hukum. Yogyakarta: Gadjah Mada University Press, 
1996.

[20] P. Negara, "Rekonstruksi Kebijakan Pengelolaan Kawasan Konservasi Berbasis Kearifan Lokal Sebagai Kontribusi Menuju Pengelolaan Sumber Daya Alam Yang Indonesia," J. Konstitusi, vol. 4, no. 2, pp. 91-138, 2011.

[21] Republik Indonesia, Undang-Undang Republik Indonesia Nomor 41 Tahun 1999 Kehutanan. Jakarta: Republik Indonesia, 1999.

[22] Republik Indonesia, Keputusan Presiden Republik Indonesia Nomor 48 Tahun 1988 Tentang Pembangunan Kelompok Hutan Sibolangit Sebagai taman Hutan Raya Bukit Barisan. Jakarta: Republik Indonesia, 1998.

[23] Republik Indonesia, Undang-Undang Republik Indonesia Nomor 5 Tahun 1990 Tentang Konservasi Sumber Daya Alam Hayati dan Ekosistemnya, Republik I. Jakarta, 1990.

[24] Republik Indonesia, Undang-Undang Republik Indonesia Nomor 32 Tahun 2009 Tentang Perlindungan dan Pengelolahan Lingkungan Hidup. Jakarta: Menteri Hukum dan Hak Asasi Manusia Republik Indonesia, 2009.

[25] E. Insusanty and Azwin, "Strategi Pengelolaan Taman Hutan Raya Sultan Syarif Hasyim Pekan baru," J. Ilm. Pertan., vol. 11, no. 2, pp. 56-68, 2014.

[26] United Nations, Transforming Our World: The 2030 Agenda for Sustainable Development. New York: United Nations, 2015.

[27] O. Fox and P. Stoett, "Citizen Participation in the UN Sustainable Development Goals Consultation Process: Toward Global Democratic Governance?," Glob. Gov. A Rev. Multilater. Int. Organ., vol. 22, no. 4, pp. 555-574, 2016.

[28] M. B. Hoelman, B. Tua, P. Parhusip, S. Eko, S. Bahagijo, and H. Santono, Panduan SDGs Untuk pemerintah Daerah (Kota dan kabupaten) dan Pemangku Kepentingan Daerah. Jakarta: Infid, 2015.

[29] J. Lahandu, R. C. Tarumingkeng, and H. Kartodihardjo, "Analisis Kebijakan Pengelolahan Akses Sumber Daya Alam oleh Masyarakat Kaili di Taman Hutan Raya (Tahura) Sulawesi Selatan,” vol. 17, pp. 24-33, 2016.

[30] M. Doctoroff, Synergistic Management: Creating the Climate for Superior Xerformance. USA: Amacom, 1977.

[31] S. Sulasmi, "Peran Variabel Perilaku Belajar Inovatif, Intensitas Kerjasama Kelompok, Kebersamaan Visi Dan Rasa Saling Percaya Dalam Membentuk Kualitas Sinergi," EKUITAS (Jurnal Ekon. dan Keuangan), vol. 13, no. 2, pp. 219-237, 2017. 